\title{
PENGGUNAAN METODE LINEAR REGRESSION UNTUK PREDIKSI PENJUALAN SMARTPHONE
}

\author{
Tri Indarwati ${ }^{1}$, Tri Irawati ${ }^{2}$, Elistya Rimawati ${ }^{3)}$ \\ ${ }^{1)}$ Program Studi: Sistem Informasi, STMIK Sinar Nusantara \\ 2) Program Studi: Komputerisasi Akuntansi, STMIK Sinar Nusantara \\ 3) Program Studi: Manajemen Informatika, STMIK Sinar Nusantara \\ 1) triindar28@gmail.com; ${ }^{2)}$ 3irawati@sinus.ac.id; ${ }^{3)}$ elistyarimawati@gmail.com
}

\begin{abstract}
Planning and analyzing market needs precisely and efficiently if managed optimally is needed to achieve company success. In practice, existing transaction data used as a reference in planning and analyzing market needs. This company needs a tool to predict future sales. This information is needed because a good sales prediction will help understand what items must be distributed according to market needs so that companies can reduce uncertainty in decision making. The purpose of this study is to create an information system can do smartphone sales forecasting at 82 Cell Mayang with the Linear Regression method. The sales forecasting system is using the Linear Regression method, The goal to create a sales forecasting system by determining the sales volume with a certain period by looking at the cost of advertising and the number of sales. The research method used includes observation, interviews and literature studies. Designing using DAD includes entity relation diagrams, context diagrams, the hierarchy of input process output and data flow diagrams. The programming language used is Visual Basic.Net and the sql server 2008 database. Features in the sales forecasting application include processing data items, customer data, incoming product data, sales data, and forecasting data. The test results show the MAPE value is 0.032 and the MSE value is 5.16. From this value, it can be said that the prediction of smartphone sales with the Linear Regression method on 82 Cell Mayang is categorized as very good. Whereas for the blackbox testing that has been carried out, it shows that the smartphone sales forecasting system in 82 Cell Mayang, Sukoharjo has been going well.
\end{abstract}

Keywords: forecasting, sales prediction, incoming product data, linear regression, visual basic

\section{PENDAHULUAN}

Perencanaan dan analisa kebutuhan pasar yang tepat dan efisien apabila dikelola secara optimal sangat dibutuhkan untuk mencapai keberhasilan perusahaan. Kendala yang dihadapi adalah data transaksi yang sudah ada selama ini belum dapat digunakan secara optimal untuk dijadikan acuan dalam perencanaan dan analisa kebutuhan pasar. Perkembangan teknologi smartphone yang sangan cepat berdampak pada penjualan yang dilakukan. Adapun perusahaan telah melakukan pembalian barang yang berlebih sedangkan distribusi barang yang tidak seimbang, sehingga banyak barang yang tidak terjual dikarenakan perkembangan model smartphone yang begitu pesat. Perusahaan ini membutuhkan sebuah alat bantu untuk memprediksi penjualan yang terjadi di masa depan. Informasi ini dibutuhkan karena prediksi penjualan yang baik akan membantu memahami berapakah barang yang harus didistribusi sesuai dengan kebutuhan pasar sehingga perusahaan dapat mengurangi ketidakpastian dalam pengambilan keputusan, membantu manajemen untuk bertindak lebih baik, membantu manajemen untuk mengenali lingkungan pasar.

Peramalan adalah salah satu unsur statistika yang sangat penting dalam pengambilan keputusan. Salah satu metode peramalan adalah metode deret berkala. Metode deret berkala merupakan metode peramalan yang memperkirakan penjualan/permintaan periode yang akan datang dengan menggunakan data histori. Jenis metode yang termasuk dalam metode deret berkala diantanya : Weighted Moving Averages, Exponential Smoothing, Linear Regression dan Seasonal Trend. Metode Linear Regresion memiliki keunggulan yaitu metode ini dapat melakukan analisis dengan menggunakan beberapa variable bebas $(X)$ sehingga hasil prediksi bisa lebih akurat. 
Perkembangan teknologi informasi memungkinkan pengolahan data dilakukan dalam waktu singkat. Salah satu solusi yang dapat dipakai untuk kasus ini adalah peramalan menggunakan sistem informasi. VB. NET merupakan sebuah tools yang digunakan untuk membuat sistem informasi. Berdasarkan permasalahan tersebut, Penulis mengambil tema penelitian dengan topik Prediksi Penjulan Smartphone Menggunakan Metode Linear Regression Pada 82 Cell Mayang, Sukoharjo. Adapaun Tujuan penelitian ini adalah untuk membuat sistem informasi yang dapat melakukan peramalan penjualan smartphone pada 82 Cell Mayang dengan metode Linear Regression.

\section{TINJAUAN PUSTAKA}

\subsection{Penjualan}

Penjualan adalah suatu usaha yang terpadu untuk mengembangkan rencanarencana strategis yang diarahkan pada usaha pemuasan kebutuhan dan keinginan pembeli guna mendapatkan penjualan yang menghasilkan laba. Penjualan merupakan sumber hidup suatu perusahaan, karena dari perusahaan dapat diperoleh laba serta suatu usaha memikat konsumen yang diusahakan untuk mengetahui daya tarik mereka sehingga dapat mengetahui hasil produk yang dihasilkan. Penjualan adalah jumlah yang dibebankan Pembeli untuk barang dagang yang diserahkan merupakan pendapatan perusahaan yang bersangkutan[1].

\subsection{Peramalan}

Peramalan adalah seni dan ilmu untuk memprediksi kejadian di masa depan dengan melibatkan pengambilan data historis dan memproyeksikannya ke masa mendatang dengan model pendekatan sistematis[2].

Adapun tahapan peramalan secara ringkas terdapat tiga tahapan yang harus dilalui dalam perancangan suatu metode peramalan, yaitu :

1. Melakukan analisa pada data masa lampau. Langkah ini bertujuan untuk mendapatkan gambaran pola dari data bersangkutan.

2. Memilih metode yang akan digunakan. Terdapat bermacam-macam metode yang tersedia dengan keperluannya. Pemilihan metode dapat mempengaruhi hasil ramalan. Hasil ramalan diukur dengan menghitung error atau kesalahan terkecil. Oleh karena itu, tidak ada metode peramalan yang pasti baik untuk semua jenis data.

3. Proses transformasi dari data masa lampau dengan menggunakan metode yang dipilih.

Apabila diperlukan maka diadakan perubahan sesuai kebutuhannya.

\subsection{Metode Linear Regresion}

Linear Regresi merupakan solusi yang cocok untuk digunakan oleh perusahaan multiproduk karena dengan memperkirakan berbagai kombinasi produk, perusahaan dapat memaksimalkan keuntungan serta memperkirakan jumlah produksi yang tepat. Namun dalam menerapkan regresi linear diperlukan pengetahuan mengenai kombinasi produk yang tepat, target pasar, serta jumlah permintaan terhadap produk itu sendiri [3].

Rumus untuk Linear Regresion dengan metode kuadrat terkecil adalah :

$$
\begin{aligned}
& \mathrm{a}=\frac{\left(\sum y\right)\left(\sum \mathrm{x}^{2}\right)-\left(\sum \mathrm{x}\right)\left(\sum y x\right)}{\mathrm{n}\left(\sum \mathrm{x}^{2}\right)-\left(\sum \mathrm{x}\right)^{2}} \ldots \ldots \ldots \ldots \ldots \ldots \ldots \ldots \ldots \ldots \ldots \ldots \ldots \\
& \mathrm{b}=\frac{\mathrm{n}\left(\sum \mathrm{xy}\right)-\left(\sum \mathrm{x}\right)\left(\sum y\right)}{\mathrm{n}\left(\sum \mathrm{x}^{2}\right)-\left(\sum \mathrm{x}\right)^{2}} \ldots \ldots \ldots \ldots \ldots \ldots \\
& \mathrm{y}=\mathrm{a}+\mathrm{b} \cdot \mathrm{x} 1+\mathrm{b} . \mathrm{x} 2 \ldots \ldots \ldots \ldots \ldots \\
& \text { Keterangan } \\
& \mathrm{y}: \text { Volume Penjualan } \\
& \mathrm{x} 1: \text { Biaya lklan } \\
& \mathrm{x} 2: \text { Jumlah Sales } \\
& \mathrm{a} \quad \text { : Konstanta yang menunjukan } \\
& \mathrm{b} \quad \text { besarnya nilai y apabila } \mathrm{x}=0
\end{aligned}
$$

\subsection{Visual basic}

Visual basic .NET 2010 adalah salah satu bahasa pemrograman yang tergabung dalam Microsoft visual studio 2010. Visual basic .NET 2010 mempunyai suatu jendela yang luas sebagai ruangan kerjanya. Jendela-jendela tersebut diantaranya adalah : Menubar, toolbox, toolbar, form windows, code windows, solution explorers windows, property windows dan jendela-jendela lain[4].

\subsection{Database}

Database adalah sekumpulan data tersebar yang berhubungan secara logis, dan penjelasan dari data ini dirancang untuk memenuhi kebutuhan informasi dari suatu organisasi. Sedangkan DBMS adalah sebuah sistem software yang memungkinkan pengguna untuk mendefinisikan, membuat, me-maintain, dan mengontrol akses ke database [5].

\subsection{Penelitian Terdahulu}


Penggunaan linear regression terkait dengan prediksi terhadap volume penjualan dilakukan oleh Inti Sariani Jianti Djie, 2013 pada PT Primajaya Pantes Garment, peramalan yang paling tepat pada perusahaan adalah metode regresi linear dengan nilai MAD dan MSE terkecil. Hasil peramalan dengan metode regresi linear digunakan perusahaan sebagai standar ukuran untuk periode berikutnya [6]. Maulina, 2014 bahwa sistem prediksi persediaan barang telah diberhasil dibuat berbasis website dengan Bahasa pemrograman PHP-MySQL dan metode regresi linier diimplementasikan untuk proses prediksi persediaan untuk triwulan selanjutnya menggunakan data penjualan. Hasil dari implementasi sistem dapat digunakan untuk membantu memprediksi persediaan barang untuk triwulan selanjutnya[7]. penelitian serupa Pyang dilakukan oleh Rival, bahwa mendapatkan hasil / peramalan yang sesuai dengan aktivitas sebenarnya maka dibutuhkanlah perhitungan menggunakan perhitungan Regresi Linier untuk menentukan tingkat penjualan pada hari yang akan datang.[8]. Persamaan regresi digunakan dalam pengukuran kinerja dimana terdapat multikolenieritas ini terlihat dari besarnya nilai korelasi antar variabel bebas yang mendekati 1 dan seluruh nilai VIF lebih 10 [9].

\section{METODE PENELITIAN}

Metode yang digunakan dalam penelitian ini meliputi observasi, wawancara dan studi pustaka. Data yang diperoleh terdiri dari histori perusahaan dan data histori penjualan.

Metode Linear Regresion merupakan metode dengan teknik peramalan kuantitatif statistik yang pada umumnya menggunakan data historis yang menitikberatkan pada pola, perubahan pola, dan faktor gangguan yang disebabkan oleh pengaruh acak

Variabel dalam penelitian ini terdiri dari variabel independen $(X)$ dan variabel dependen ( $Y$ ). Variabel $X$ yang digunakan adalah biaya iklan (x1) dan jumlah sales (x2), dan variabel $Y$ adalah volume penjualan $(\mathrm{y})$.

Desain sistem yang dibuat meliputi entity relation diagram, context diagram, hierarchy input process output, data flow diagram dan memakai pemodelan Entity Relationship Diagram (ERD).

Sistem dibangun menggunakan bahasa pemrograman Visual Basic.Net dan database SQL Server. Pengujian menggunakan black box dan uji validitas data.

\section{IV.HASIL DAN PEMBAHASAN}

\subsection{Perancangan Penelitian}

1. Entity relation diagram(ERD), Adapun rancangan ERD dapat dilihat pada Gambar 1.

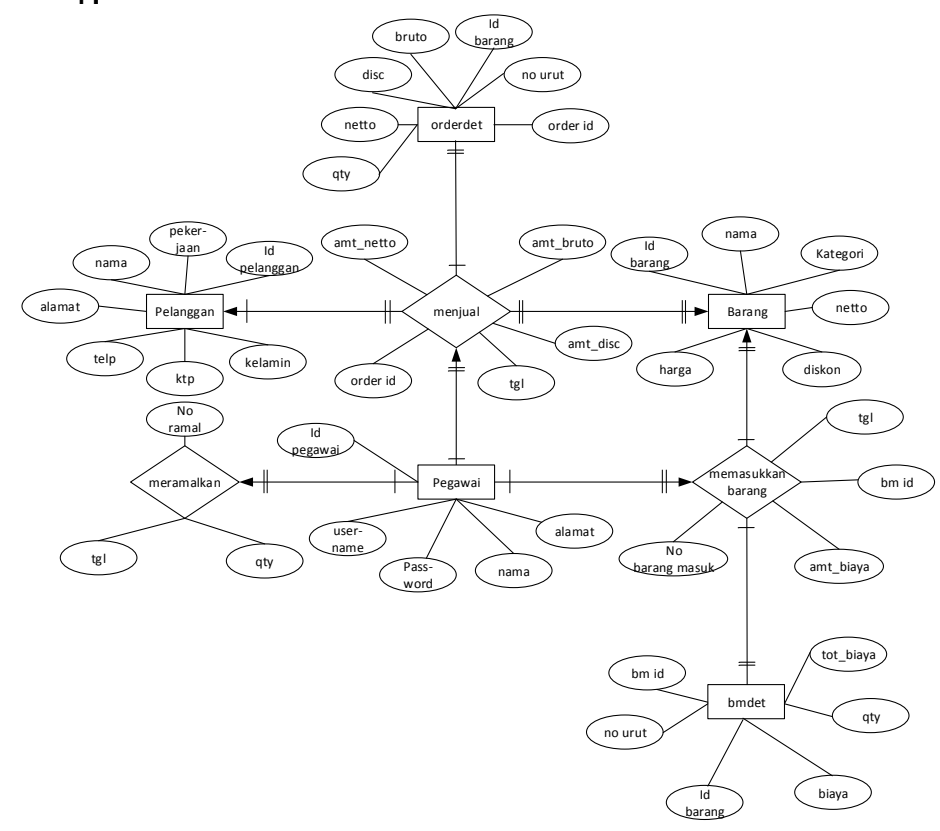

Gambar 1. Entity Relation Diagram

2. Context diagram, entitas yang terlibat adalah pelanggan, administrasi, bagian gudang dan pimpinan. Adapun gambaran kontek diagram dapat dilihat dalam Gambar 2.

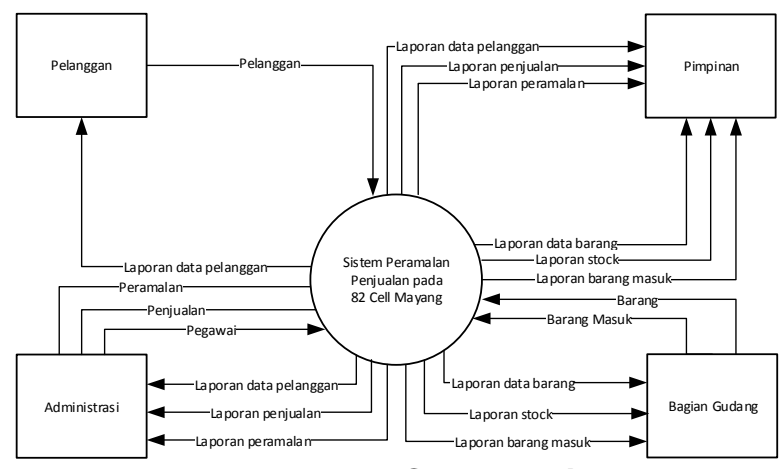

Gambar 2. Context Diagram

3. HIPO, Diagram ini menggambarkan tentang program secara terstruktur, yang berfungsi untuk memelihara program secara memperjelas batasan program. 


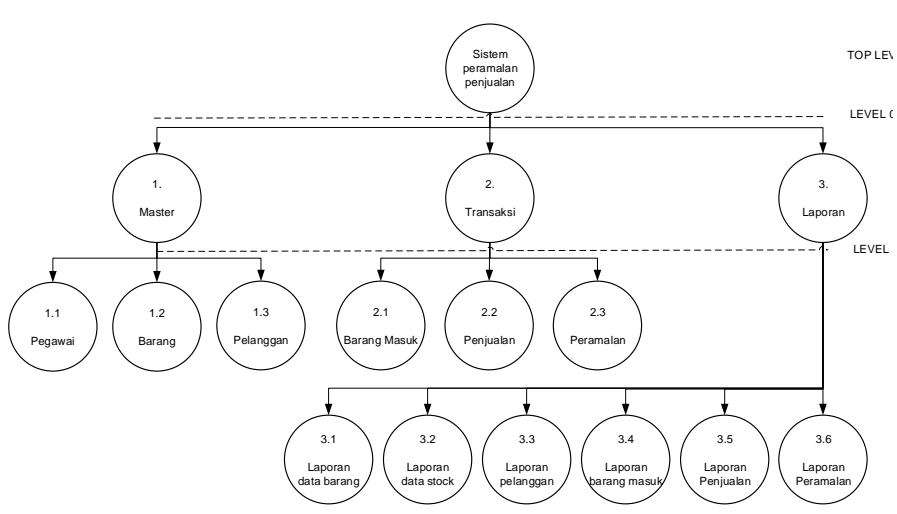

Gambar 3. HIPO

4. Diagram Arus Data (DAD), sebagai media untuk menjelaskan semua alur data beserta proses-proses yang terdapat di dalam sistem dapat dilihat pada Gambar 3.

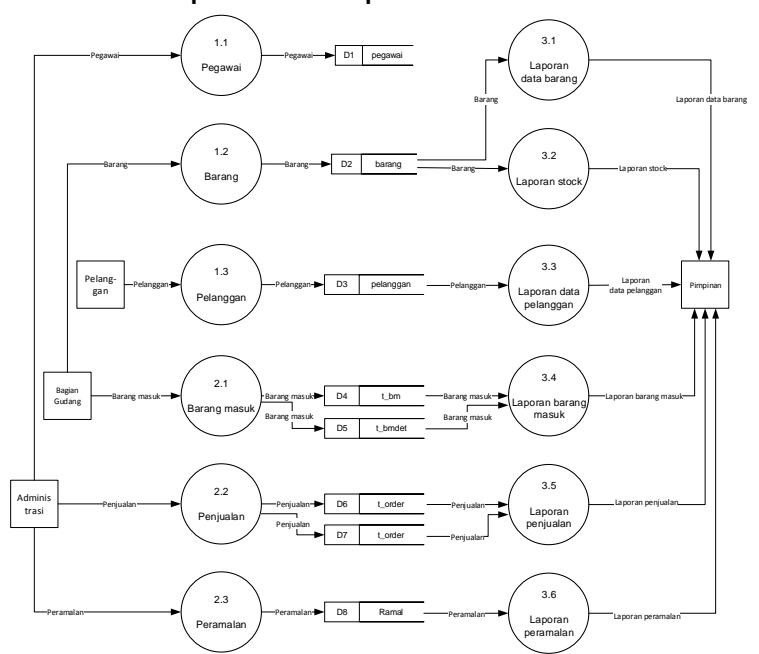

Gambar 4. DFD Level 0

\subsection{Proses Perhitungan Linear Regresi}

Berikut merupakan perhitungan untuk meramalkan jumlah smartphone Lenovo pada periode selanjutnya dengan biaya iklan 2 juta dengan menggunakan data penjualan tahun 2016. Data penjulan ini dapat diihat dalam Tabel 1.

Tabel 1. Data penjualan smartphone periode 2014-2016

\begin{tabular}{|c|c|c|c|c|c|c|c|}
\hline $\mathbf{n}$ & $\mathbf{y}$ & $\mathbf{x 1}$ & $\mathbf{x 2}$ & $\mathbf{x 1}^{\mathbf{2}}$ & $\mathbf{x 2}^{\mathbf{2}}$ & $\mathbf{y}^{\mathbf{2}}$ & $\mathbf{y . x ^ { 2 }}$ \\
\hline 1 & 58 & 1 & 2 & 1 & 4 & 3364 & 2 \\
\hline 2 & 70 & 1 & 2 & 1 & 4 & 4900 & 2 \\
\hline 3 & 62 & 1 & 2 & 1 & 4 & 3844 & 2 \\
\hline 4 & 74 & 1 & 2 & 1 & 4 & 5476 & 2 \\
\hline 5 & 62 & 1 & 2 & 1 & 4 & 3844 & 2 \\
\hline 6 & 68 & 2 & 4 & 4 & 16 & 4624 & 8 \\
\hline 7 & 72 & 2 & 4 & 4 & 16 & 5184 & 8 \\
\hline 8 & 80 & 1 & 2 & 1 & 4 & 6400 & 2 \\
\hline 9 & 60 & 1 & 2 & 1 & 4 & 3600 & 2 \\
\hline 10 & 60 & 1 & 2 & 1 & 4 & 3600 & 2 \\
\hline 11 & 72 & 2 & 4 & 4 & 16 & 5184 & 8 \\
\hline 12 & 68 & 1 & 2 & 1 & 4 & 4624 & 2 \\
\hline 4
\end{tabular}

\begin{tabular}{|c|c|c|c|c|c|c|c|}
\hline $\mathbf{n}$ & $\mathbf{y}$ & $\mathbf{x 1}$ & $\mathbf{x 2}$ & $\mathbf{x 1}^{\mathbf{2}}$ & $\mathbf{x 2}^{\mathbf{2}}$ & $\mathbf{y}^{\mathbf{2}}$ & $\mathbf{y . \mathbf { x } ^ { \mathbf { 2 } }}$ \\
\hline 13 & 62 & 1 & 1 & 1 & 1 & 3844 & 1 \\
\hline 14 & 74 & 1 & 2 & 1 & 4 & 5476 & 2 \\
\hline 15 & 66 & 1 & 2 & 1 & 4 & 4356 & 2 \\
\hline 16 & 78 & 2 & 4 & 4 & 16 & 6084 & 8 \\
\hline 17 & 66 & 1 & 2 & 1 & 4 & 4356 & 2 \\
\hline 18 & 72 & 2 & 4 & 4 & 16 & 5184 & 8 \\
\hline 19 & 76 & 2 & 4 & 4 & 16 & 5776 & 8 \\
\hline 20 & 84 & 2 & 4 & 4 & 16 & 7056 & 8 \\
\hline 21 & 64 & 1 & 2 & 1 & 4 & 4096 & 2 \\
\hline 22 & 64 & 1 & 2 & 1 & 4 & 4096 & 2 \\
\hline 23 & 76 & 2 & 4 & 4 & 16 & 5776 & 8 \\
\hline 24 & 72 & 1 & 2 & 1 & 4 & 5184 & 2 \\
\hline 25 & 60 & 2 & 4 & 4 & 16 & 3600 & 8 \\
\hline 26 & 72 & 2 & 4 & 4 & 16 & 5184 & 8 \\
\hline 27 & 64 & 2 & 4 & 4 & 16 & 4096 & 8 \\
\hline 28 & 76 & 1 & 2 & 1 & 4 & 5776 & 2 \\
\hline 29 & 64 & 1 & 2 & 1 & 4 & 4096 & 2 \\
\hline 30 & 70 & 1 & 2 & 1 & 4 & 4900 & 2 \\
\hline 31 & 74 & 1 & 2 & 1 & 4 & 5476 & 2 \\
\hline 32 & 82 & 2 & 4 & 4 & 16 & 6724 & 8 \\
\hline 33 & 62 & 2 & 4 & 4 & 16 & 3844 & 8 \\
\hline 34 & 62 & 2 & 4 & 4 & 16 & 3844 & 8 \\
\hline 35 & 74 & 2 & 4 & 4 & 16 & 5476 & 8 \\
\hline 36 & 70 & 1 & 2 & 1 & 4 & 4900 & 2 \\
\hline $\mathbf{J m l}$ & $\mathbf{2 4 9 0}$ & $\mathbf{5 1}$ & $\mathbf{1 0 1}$ & $\mathbf{8 1}$ & $\mathbf{3 2 1}$ & $\mathbf{1 7 3 8 4 4}$ & $\mathbf{1 6 1}$ \\
\hline & & & & & & & \\
\hline
\end{tabular}

Berdasarkan Rumus (1) Perhitungan nilai X1 dan X2 adalah:

$$
\begin{aligned}
\sum \mathrm{x}_{1}^{2} & =\sum \mathrm{x}_{1}^{2}-\frac{\left(\sum \mathrm{x} 1\right)^{2}}{\mathrm{n}} \\
& =81-\frac{2601}{36}=8.75 \\
\sum \mathrm{x}_{2}{ }^{2} & =\sum \mathrm{x}_{2}^{2}-\frac{\left(\sum \mathrm{x} 2\right)^{2}}{\mathrm{n}} \\
& =321-\frac{10201}{36}=37,64
\end{aligned}
$$

Sedangkan untuk perhitungan nilai y menggunakan Rumus (2) sebagai berikut:

$$
\begin{aligned}
& \sum \mathrm{y}^{2}=\sum \mathrm{y}^{2}-\frac{\left(\sum \mathrm{y}\right)^{2}}{\mathrm{n}} \\
& =173844-\frac{6200100}{36}=1619 \\
& \sum \mathrm{x}_{1} \mathrm{y}=\sum \mathrm{x}_{1 .} \mathrm{y}-\frac{\sum \mathrm{x} 1 . \sum \mathrm{y}}{\mathrm{n}} \\
& =3564-\frac{51 * 2490}{36}=36,5 \\
& \sum \mathrm{x}_{2 .} \mathrm{y}=\sum \mathrm{x}_{2 . \mathrm{y}}-\frac{\sum \mathrm{x} 2 \cdot \sum \mathrm{y}}{\mathrm{n}} \\
& =7066-\frac{101 * 2490}{36}=80,17 \\
& \sum \mathrm{x}_{1}, \mathrm{x}_{2}=\sum \mathrm{x}_{1}, \mathrm{x}_{2}-\frac{\sum \mathrm{x} 1 \cdot \sum \mathrm{x} 2}{\mathrm{n}} \\
& =161-\frac{51 * 101}{36}=17.92
\end{aligned}
$$

Setelah memperoleh nilai $x$ dan y maka dapat menggunakan Rumus (3) dalam menghitung nilai peramalan dengan menggunakan regresi linear berganda: 


$$
\begin{aligned}
\mathrm{b}_{1}= & \frac{\left(\sum \mathrm{x} 2^{2} * \sum \mathrm{x} 1 \mathrm{y}\right)-\left(\sum \mathrm{x} 2 \mathrm{y} * \sum \mathrm{x} 1 \mathrm{x} 2\right)}{\left(\sum \mathrm{x} 1^{2} * \sum \mathrm{x} 2^{2}\right)-\left(\sum \mathrm{x} 1 \mathrm{x} 2\right)^{2}} \\
= & \frac{(37,64 * 36,5)-(80,17 * 17,92)}{(8,75 * 37,64)-(17,92)^{2}} \\
= & \frac{1373,86-1436.32}{329,35-321,13}=\frac{-62,46}{8,22} \\
= & -7,59 \\
\mathrm{~b} 2= & \frac{\left(\sum \mathrm{x} 1^{2} * \sum \mathrm{x} 2 \mathrm{y}\right)-\left(\sum \mathrm{x} 1 \mathrm{y} * \sum \mathrm{x} 1 \mathrm{x} 2\right)}{\left(\sum \mathrm{x} 1^{2} * \sum \times 2^{2}\right)-\left(\sum \mathrm{x} 1 \mathrm{x} 2\right)^{2}} \\
= & \frac{(8,75 * 80,17)-(36,5 * 17,92)}{(8,75 * 37,64)-(17,92)^{2}} \\
= & \frac{701,49-654,08}{329,35-321,12}=\frac{47,41}{8,23} \\
= & 5,76
\end{aligned}
$$

$$
\begin{aligned}
\mathrm{a}= & \frac{\left(\sum \mathrm{y}\right)-\left(\mathrm{b} 1 * \sum \mathrm{x} 1\right)-\left(\mathrm{b} 2 * \sum \mathrm{x} 2\right)}{\mathrm{n}} \\
& =\frac{2490-(-7,59 * 51)-(5,76 * 101)}{36} \\
& =\frac{2490-(-387,09)-(581,76)}{36} \\
& =63,76
\end{aligned}
$$$$
y=63,76+(-7,59) \times 1+(5,76) \times 2
$$

Jadi nilai tren peramalan untuk jenis smartphone Lenovo adalah $\mathrm{y}=63,76+(-$ $7,59 \times 1+(5,76) \times 2$. Jika ingin meramalkan periode selanjutnya dengan biaya iklan 2 Juta, dan jumlah sales 4 maka $63,76+(-7,59) 2$ $+(5,76) 4=71,62=72$ Unit.

\subsection{Hasil Implementasi Sistem}

Dalam bahasan ini akan dijelaskan tentang urutan penggunaan program sistem informasi peramalan penjualan pada 82 Cell Mayang. Menu-menu yang tersedia adalah pengolahan data Pegawai, data pelanggan, data barang, barang masuk, penjualan, peramalan, Laporan data pelanggan, Laporan data barang, Laporan barang masuk, Laporan stock barang, Laporan penjualan.

\section{Form Barang}

Menu barang digunakan untuk mengolah data barang, mulai dari mencari, menambah, mengubah dan menghapus barang bisa dilakukan di menu ini. Gambar 5 berikut merupakan tampilan menu barang.

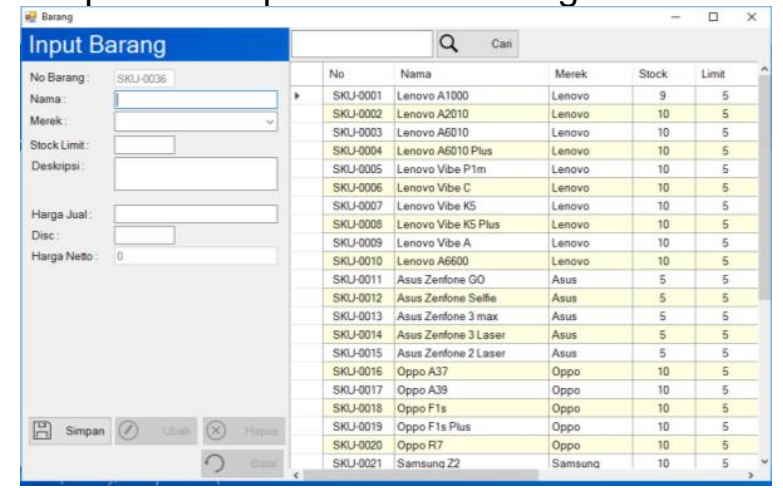

Gambar 5. Form barang

\section{Form Penjualan}

Menu penjualan digunakan untuk mengolah data penjualan, dimana pengguna dapat menambahkan pelanggan dan barangbarang apa saja yang dijual. Pengguna juga dapat menambahkan diskon setiap barang seperti pada Gambar 6 .

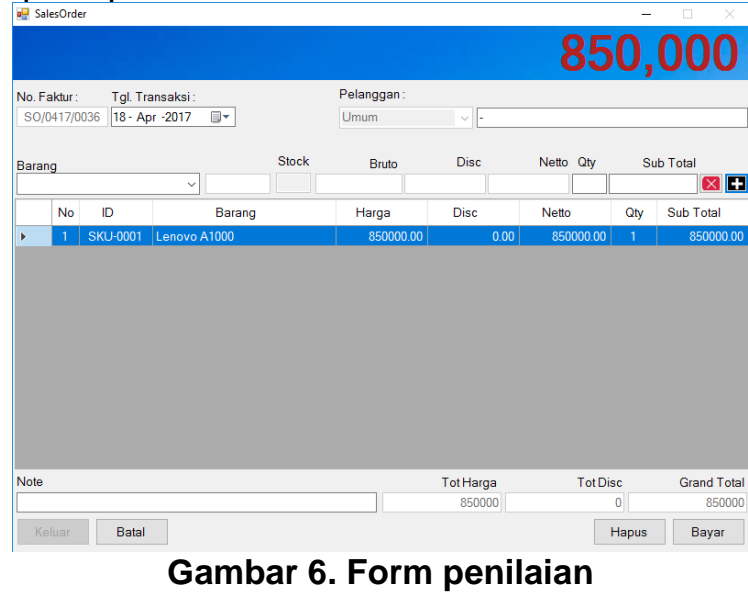

3. Form Peramalan

Menu peramalan digunakan untuk meramalkan jumlah penjualan yang akan datang berdasarkan data penjualan yang sudah ada, dimana pengguna dapat meramalkan berdasarkan setiap jenis/merek smartphone seperti dalam Gambar 7 .

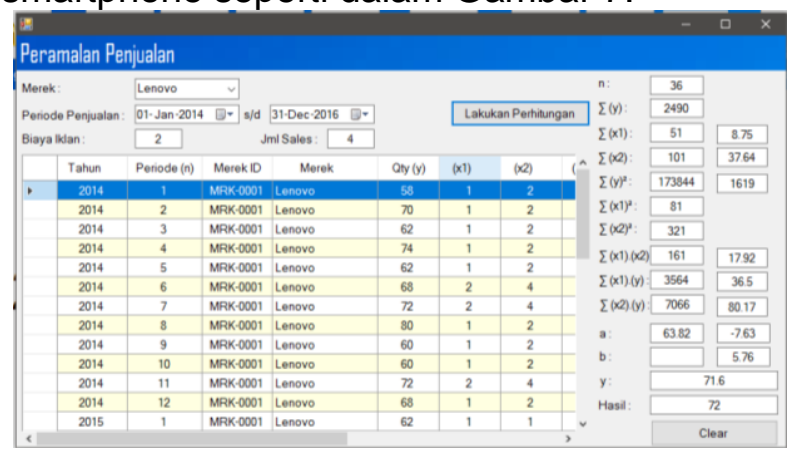

Gambar 7. Form peramalan

Sesuai dengan teori dan metode yang digunakan, peramalan penjualan dihitung berdasarkan data histori transaksi penjualan smartphone.

\subsection{Pengujian MAPE dan MSE}

Untuk mengetahui akurasi hasil peramalan penjualan smartphone Lenovo, maka dilakukan perhitungan untuk mengetahui tingkat kesalahan dengan menggunakan MAPE (Mean Absolute Percentage Error). Nilai MAPE dapat dikatakan sangat baik apabila nilai tersebut kurang dari 10\%. Pada Tabel 2 dan Tabel 3 berikut merupakan takaran kriteria MAPE. 
Tabel 2. Kriteria MAPE

\begin{tabular}{|l|l|}
\hline MAPE & Keterangan \\
\hline$<10 \%$ & Sangat baik \\
\hline $10 \%-<20 \%$ & Baik \\
\hline $20 \%-<50 \%$ & Cukup \\
\hline$>50 \%$ & Buruk \\
\hline
\end{tabular}

Tabel 3. Tabel Pengujian

\begin{tabular}{|c|c|c|c|c|}
\hline $\mathbf{n}$ & Real & Prediksi & MAPE & MSE \\
\hline 1 & 58 & 56 & 0.034 & 4 \\
\hline 2 & 70 & 68 & 0.029 & 4 \\
\hline 3 & 62 & 60 & 0.032 & 4 \\
\hline 4 & 74 & 70 & 0.054 & 16 \\
\hline 5 & 62 & 60 & 0.032 & 4 \\
\hline 6 & 68 & 65 & 0.044 & 9 \\
\hline 7 & 72 & 70 & 0.028 & 4 \\
\hline 8 & 80 & 78 & 0.025 & 4 \\
\hline 9 & 60 & 58 & 0.033 & 4 \\
\hline 10 & 60 & 59 & 0.017 & 1 \\
\hline 11 & 72 & 70 & 0.028 & 4 \\
\hline 12 & 68 & 66 & 0.029 & 4 \\
\hline \multicolumn{3}{|c|}{ Jumlah Kesalahan } & 0.386 & 62 \\
\hline \multicolumn{3}{|c|}{ Jumlah Kesalahan / n } & 0.032 & 5,167 \\
\hline
\end{tabular}

Berdasarkan Tabel 3 tentang hasil pengujian prediksi penjualan smartphone dengan histori penjualan pada periode 2016 menunjukkan bahwa hasil uji MAPE dan MSE data yang diuji adalah presentase kesalahan kurang dari 10\%. Berdasarkan tabel kriteria MAPE menunjukkan bahwa hasil prediksi penjualan smartphone dengan metode Linear Regresi Sederhana adalah tergolong dalam kategori sangat baik.

\section{PENUTUP}

\subsection{Kesimpulan}

1. Telah berhasil dibuat sebuah aplikasi peramalan penjualan pada 82 Cell Mayang, Sukoharjo dengan menggunakan metode Linear Regresi yang sebelumnya hanya berdasarkan intuisi pemilik dalam meramalkan jumlah penjualan yang akan datang. Output dari aplikasi ini adalah jumlah barang hasil peramalan penjualan pada periode yang akan datang berdasarkan data penjualan pada periode tertentu pada 82 Cell Mayang, Sukoharjo. Data yang digunakan adalah data hasil penjualan yang sudah diinputkan sehingga tidak perlu menginput data penjualan lagi.

2. Hasil pengujian menunjukkan bahwa prediksi penjualan smartphone dengan metode Linear Regresi adalah tergolong dalam kategori sangat baik. Terbukti dengan pengujian nilai MAPE dan MSE untuk smartphone merek Lenovo kurang dari 10. Sedangkan untuk pengujian blackbox yang sudah dilakukan menunjukkan bahwa sistem peramalan penjualan smartphone di 82 Cell Mayang, Sukoharjo yang dibuat berjalan dengan baik.

\subsection{Saran}

1. Penggunaan sistem komputerisasi yang cepat dengan sumber daya yang memadai akan semakin mempermudah dalam melakukan pengolahan data penjualan dan peramalan.

2. Aplikasi sistem peramalan baru menggunakan metode Regresi Linear, sangat memungkinkan untuk ditambahkan metode-metode lain yang mendukung dengan tema serupa semisal Weighted Moving Averages, Exponential Smoothing atau Seasonal Trend.

\section{DAFTAR PUSTAKA}

[1] R. Soemarso, Pengantar Akuntansi. Jakarta: Salemba Empat, 2009.

[2] R. Heizer J, Operations management (Manajemen Operasi). Jakarta: Salemba Empat, 2009.

[3] M. Manivel, "Profit Planning of an NGO run enterprise using linear programming approach International Research Journal of Finance and Economics," Int. Res. J. Financ. Econ., p. 23, 2009.

[4] Y. Subari, Boom. Visual Studio.Net 2010 meledak. Jakarta: Cerdas Pustaka Publisher, 2010.

[5] B.T. Connoly, A Practical Approach to design, Implementation, and management. Americca: Pearson Education, 2010.

[6] Inti Sariani Jiantra Djie, "Analisis Peramalan Penjualan Dan Penggunaan Metode Linear Programming Dan Decision Tree Guna Mengoptimalkan Keuntungan," The Winners, pp. 113-119, 2013.

[7] M. F. Safitri, "Analisa Data Penjualan Menggunakan Metode Regresi Linier Untuk Prediksi Persediaan Barang," Skripsi, Prodi Teknik Informatika, Universitas Dian Nuswantoro, 2016.

[8] Z. Rival, W. S. J. Saputra, and N. K. Sari, "Aplikasi Peramalan Penjualan Menggunakan Metode Regresi Linier," Scan - J. Teknol. Inf. Dan Komun., vol. 7, no. 3, pp. 41-45, 2012.

[9] Rahmadeni dan D. Anggreni, "Analisis Jumlah Tenaga Kerja Terhadap Jumlah Pasien RSUD Arifin Achmad Pekanbaru menggunakan Metode Regresi Gulud," SiTekln, vol. 12, no. 1, pp. 48-57, 2014. 